\title{
Metabolic Effects of Acute and Prolonged Growth Hormone Excess in Normal and Insulin-deficient Man
}

\author{
P. Metcalfe ${ }^{1}$, D. G. Johnston ${ }^{2}$, R. Nosadini ${ }^{3}$, H. Ørksov ${ }^{4}$, and K. G. M. M. Alberti ${ }^{3}$ \\ ${ }^{1}$ Southampton University Medical School, Southampton, Departments of ${ }^{2}$ Medicine and ${ }^{3}$ Clinical Biochemistry and Metabolic Medicine, \\ Royal Victoria Infirmary, Newcastle upon Tyne, England, and ${ }^{4}$ Afdeling M, Kommunehospitalet, Aarhus, Denmark
}

Summary. The metabolic effects of acute $(4 \mathrm{~h})$ and
prolonged $(24 \mathrm{~h})$ growth hormone excess at
pathophysiological concentrations were studied by
growth hormone administration to normal subjects
with and without somatostatin induced insulin defi-
ciency. Acute growth hormone excess produced mild
hyperinsulinaemia, but blood glucose concentrations
were unaltered whereas chronic growth hormone
excess caused a small $(0.5 \mathrm{mmol} / \mathrm{l})$ but significant rise
in overnight-fasting blood glucose concentration
together with a similar rise in fasting insulin levels
(Mean \pm SEM $9 \pm 1 \mathrm{v} 4 \pm 1 \mathrm{mU} / \mathrm{l}$, p $<0.01)$. When
insulin secretion was suppressed by somatostatin, a
hyperglycaemic effect of acute growth hormone
excess was unmasked, and the hyperglycaemic effect
of chronic growth hormone excess was exaggerated. Acute growth hormone administration without somatostatin had a mild ketogenic action despite stimulated insulin secretion but no change in plasma non-esterified fatty acid or blood glycerol levels was observed. Somatostatin magnified the ketogenic effect of acute growth hormone excess, and unmasked a lipolytic action. Prolonged growth hormone excess had a lipolytic action that was increased by somatostatin, although the ketogenic effect of growth hormone was only seen during somatostatin induced insulin deficiency. The acute hyperglycaemic, lipolytic and ketogenic actions of growth hormone in normal subjects are limited by a compensatory rise in insulin secretion although with chronic exposure hyperglycaemic and lipolytic effects are seen. In insulin-deficient states, however, elevated growth hormone levels could be important in promoting hyperglycaemia and hyperketonaemia.

Key words: Growth hormone, insulin, insulin deficiency, glucagon, blood glucose, ketone bodies, ketogenesis, lipolysis, non-esterified fatty acids
Serum growth hormone concentrations are inappropriately elevated in "juvenile onset" diabetics with the highest levels found in the most poorly controlled subjects [1-4]. Nevertheless the contribution of growth hormone to the metabolic abnormalities of diabetes is uncertain. Previous studies have demonstrated hyperglycaemic, lipolytic and ketogenic actions of growth hormone in normal, diabetic, and hypophysectomised man and animals [5-10]. Many of the growth hormone preparations used in the older studies were contaminated with other peptides and the doses were often pharmacological. More recently the lipolytic and ketogenic effects of growth hormone have been demonstrated in severely insulin-deficient diabetics [11], but few data are available in normal man. In the present study we have investigated the metabolic actions of acute and prolonged growth hormone excess in normal subjects and in subjects rendered partially insulin-deficient by infusion of somatostatin.

\section{Subjects and Methods}

\section{Protocol}

1. Acute Studies. Six normal subjects, mean age 29 years (range $20-40$ years), per cent ideal body weight $104 \pm 3$ (mean \pm SEM), were studied after an overnight $(12 \mathrm{~h})$ fast. Dietary carbohydrate intake was more than $300 \mathrm{~g}$ daily for at least $48 \mathrm{~h}$ before study and no subject was taking any drugs. All had normal liver and renal function tests. Intravenous Venflon (Viggo) cannulae were positioned in both antecubital fossae between $0800 \mathrm{~h}$ and $0815 \mathrm{~h}$. Subjects remained recumbent throughout the test. On four separate occasions, with at least one week between infusions, subjects received one of the following continuous intravenous infusion regimes.

(1) $\mathrm{NaCl}(0.154 \mathrm{~mol} / 1$, total volume $30-50 \mathrm{ml})$ for $240 \mathrm{~min}$;

(2) synthetic linear somatostatin (Ferring), $100 \mu \mathrm{g} / \mathrm{h}$, in NaCl $(0.154 \mathrm{~mol} / 1,30-50 \mathrm{ml})$ for $240 \mathrm{~min}$;

(3) human growth hormone (Kabi) $500 \mu \mathrm{g} / \mathrm{h}$ in $\mathrm{NaCl}$ $(0.154 \mathrm{~mol} / 1,30-50 \mathrm{ml})$ for $240 \mathrm{~min}$; 

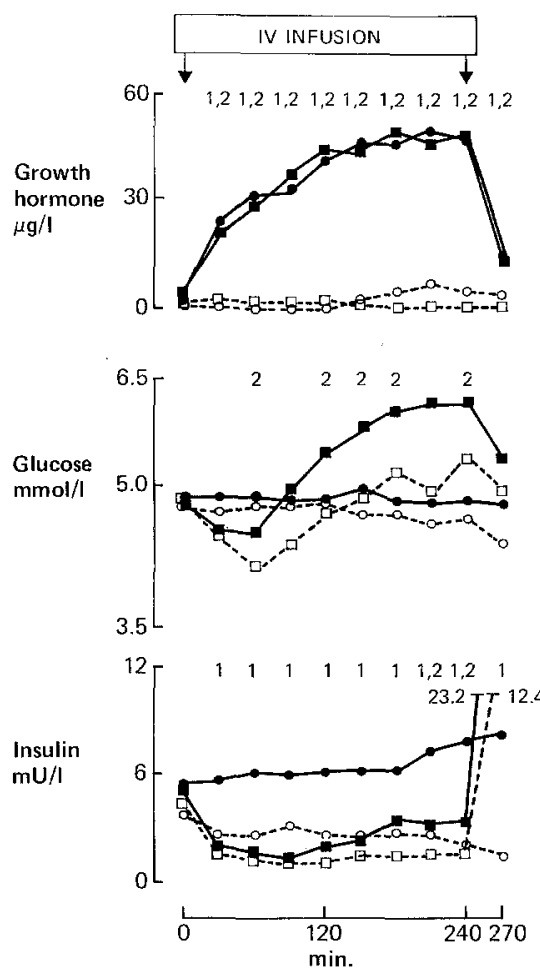

Fig. 1. Serum growth hormone, blood glucose and serum insulin response to intravenous infusion of saline and human growth hormone $(500 \mu \mathrm{g} / \mathrm{h})$ with and without somatostatin $(100 \mu \mathrm{g} / \mathrm{h}) .1=$ values during growth hormone infusion significantly different from saline at $5 \%$ level or less. $2=$ values during infusion of both growth hormone and somatostatin significantly different from somatostatin alone at $5 \%$ level or less. Values are the mean of 6 subjects. $\mathrm{O}---\mathrm{O}$ saline infusion, - growth hormone infusion, $\square--\square$ somatostatin infusion, $\square$ - somatostatin plus growth hormone infusion

(4) human growth hormone $(500 \mu \mathrm{g} / \mathrm{h})$ plus somatostatin $(100 \mu \mathrm{g} / \mathrm{h})$ for $240 \mathrm{~min}$.

Two basal blood samples were taken 25 and $30 \mathrm{~min}$ after cannulation, and then the continuous intravenous infusion was started. Further blood samples were taken at $30 \mathrm{~min}$ intervals for $270 \mathrm{~min}$.

2. Prolonged Studies. Five normal subjects previously studied in the acute experiments also participated in the chronic studies (mean age 27 years, per cent ideal body weight $103 \pm 3$ ). Subject preparation and cannulation was as for the acute studies, with infusion studies after an overnight fast. At intervals at least 2 weeks apart, subjects received intramuscular injections of human growth hormone (Kabi), $2 \mathrm{mg}, 24 \mathrm{~h}$ and $12 \mathrm{~h}$ before continuous intravenous infusion of

(1) $\mathrm{NaCl}(0.154 \mathrm{~mol} / 1,30-50 \mathrm{ml})$, for $240 \mathrm{~min}$; or

(2) synthetic linear somatostatin (Ferring), $100 \mu \mathrm{g} / \mathrm{h}$ in $\mathrm{NaCl}$ $(0.154 \mathrm{~mol} / 1,30-50 \mathrm{ml})$ for $240 \mathrm{~min}$.

Blood samples were taken at the same times as for the acute experiments.

In two subjects, blood for growth hormone estimation was taken at $30 \mathrm{~min}$ intervals for $12 \mathrm{~h}$ after a single $2 \mathrm{mg} \mathrm{IM}$ growth hormone injection. Levels peaked at $3.5 \mathrm{~h}(15$ and $19 \mu \mathrm{g} / \mathrm{l})$ with a return to baseline at $12 \mathrm{~h}$.

Informed consent was obtained from all subjects before the study, which was approved by the Southampton Hospitals Ethical Committee.

\section{Chemical Methods}

Blood for glucose, 3-hydroxybutyrate, lactate, pyruvate, glycerol and alanine estimation was taken in ice-cold $5 \% \mathrm{w} / \mathrm{v}$ perchloric acid and assayed by automated fluorimetric enzymatic methods within $24 \mathrm{~h}$ [12]. Acetoacetate was measured by an automated spectrophotometric method on the perchlorate samples within $24 \mathrm{~h}$ [13]. Plasma nonesterified fatty acids (NEFA) were measured by a radioactive cobalt method [14] and serum triglyceride as glycerol after hydrolysis [15]. Serum growth hormone [16] and insulin [17] were measured by double antibody radioimmunoassay. Blood samples $(2.25 \mathrm{ml})$ for glucagon assay were collected into $0.25 \mathrm{ml}$ aprotonin (2500 I. U.) containing 25 umole EDTA and plasma glucagon measured by radio-immunoassay [18]. Serum cortisol was measured by competitive protein binding [19].

Statistical analysis was performed using Student's t-test for paired data. Values are given as mean \pm SEM.

\section{Results}

\section{Acute Studies}

Hormonal Changes. The effects of saline infusion alone on hormone levels are shown in Figure 1 and Table 1. Growth hormone showed the expected intermittent spontaneous surges in individuals. Insulin levels gradually decreased over the $4 \mathrm{~h}$. Glucagon showed no significant change. Somatostatin infusion resulted in a $50 \%$ decrease in circulating serum insulin concentrations ( $\mathrm{p}<0.05$, from 90 to $180 \mathrm{~min}$ ) (Fig. 1) and a $30-40 \%$ decrease in plasma glucagon levels (Table 1). Basal serum growth hormone concentrations were unaffected but the spontaneous surges in growth hormone secretion seen during saline infusion were absent. A rebound in secretion of insulin and glucagon was evident after the end of the somatostatin infusion.

Growth hormone infusion produced serum levels of $40-50 \mu \mathrm{g} / 1$ at $4 \mathrm{~h}$. This produced a mild elevation in circulating serum insulin concentrations compared with the saline control (Fig. 1). During growth hormone plus somatostatin infusion a $50 \%$ decrease in circulating serum insulin concentrations was seen compared with growth hormone infusion alone. Some escape of insulin secretion occurred after $3 \mathrm{~h}$ combined growth hormone and somatostatin administration with insulin levels $40 \%$ higher at this stage than during somatostatin infusion alone. Nonetheless, continued suppression was evident from the insulin rebound observed on cessation of the infusion. No effect of growth hormone on plasma glucagon or serum cortisol concentrations was evident at any time (Table 1).

Metabolite Changes. Saline infusion resulted in a gradual fall in glucose concentrations. After an initial decline, significant at 60 and $90 \mathrm{~min}$, somatostatin alone caused a progressive rise in blood glucose levels towards the end of the infusion (blood glucose at $240 \mathrm{~min}, 5.4 \pm 0.3 \mathrm{mmol} / 1$ with somatostatin; 4.6 $\pm 0.2 \mathrm{mmol} / 1$ with saline, $\mathrm{p}<0.05$ ). 
Table 1. Serum or plasma hormone and blood metabolite concentrations during intravenous saline, somatostatin and growth hormone infusions

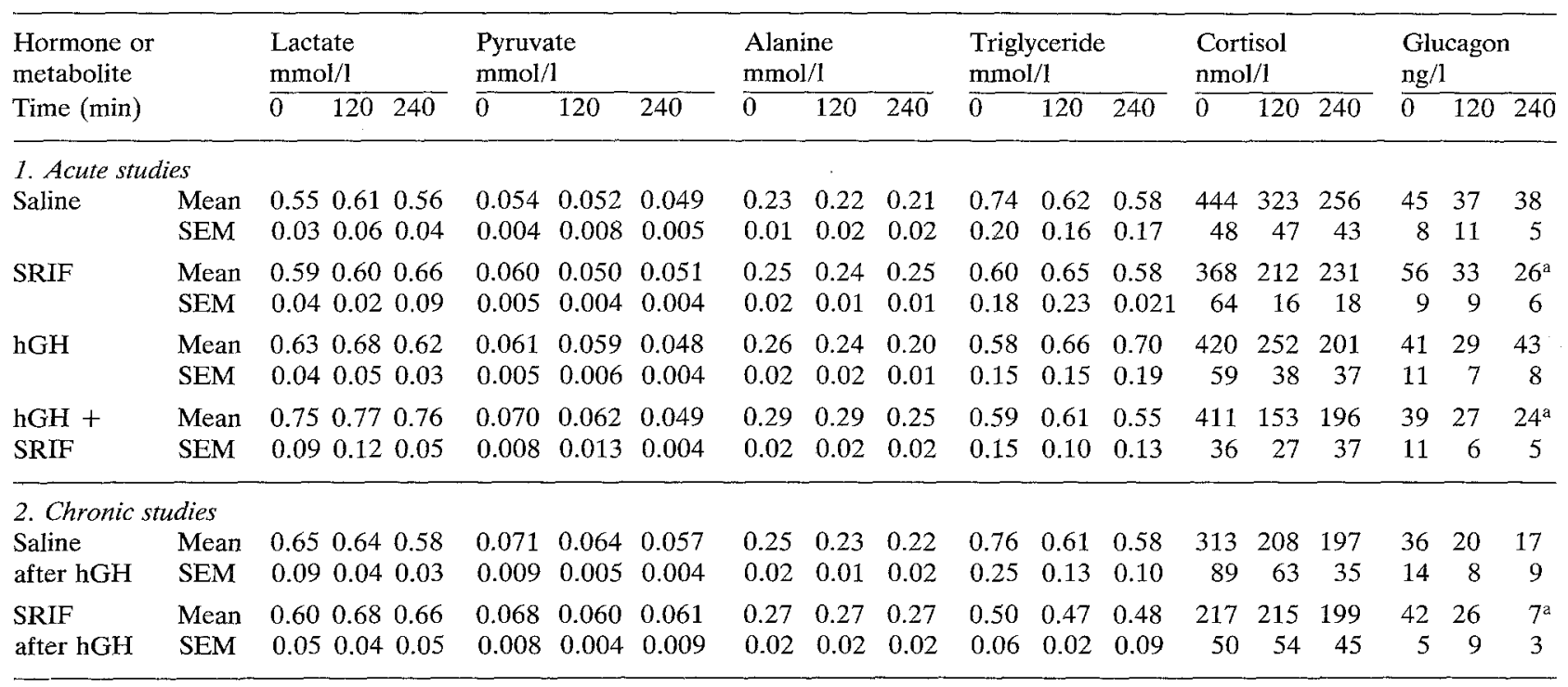

Saline $=$ IV $0.154 \mathrm{~mol} / 1$ sodium chloride, $30-50 \mathrm{ml}$ in $4 \mathrm{~h}$

$\mathrm{SRIF}=\mathrm{IV}$ somatostatin, $100 \mu \mathrm{g} / \mathrm{h}$ for $4 \mathrm{~h}$

$\mathrm{hGH}=\mathrm{IV}$ human growth hormone, $500 \mu \mathrm{g} / \mathrm{h}$ for $4 \mathrm{~h}$

$\mathrm{hGH}+\mathrm{SRIF}=$ IV somatostatin $100 \mu \mathrm{g} / \mathrm{h}$ plus IV human growth hormone $500 \mu \mathrm{g} / \mathrm{h}$ for $4 \mathrm{~h}$

Saline after hGH $=$ IV $0.154 \mathrm{~mol} / 1$ sodium chloride after $2 \mathrm{mg} \mathrm{hGH} \mathrm{IM} 24 \mathrm{~h}$ and $12 \mathrm{~h}$ earlier

Somatostatin after hGH = IV somatostatin, $100 \mu \mathrm{g} / \mathrm{h}$, after $2 \mathrm{mg} \mathrm{hGH} \mathrm{IM} 24 \mathrm{~h}$ and $12 \mathrm{~h}$ earlier

Values given as mean \pm SEM

a Saline or growth hormone infusion significantly different $(\mathrm{p}<0.05)$ from corresponding somatostatin or growth hormone plus somatostatin infusion respectively, by Student's t-test for paired data

Blood glucose concentrations were not altered over the four hour infusion of growth hormone alone. During combined growth hormone and somatostatin infusion blood glucose levels were higher than those seen during somatostatin infusion alone, evident by $60 \mathrm{~min}$ and continuing throughout the infusion period (Fig. 1).

Plasma NEFA concentrations were similar during growth hormone, somatostatin and saline infusions but a minor rise in blood glycerol was induced by growth hormone by $240 \mathrm{~min}$ (Fig. 2). In contrast combined growth hormone and somatostatin infusion caused a rise in both plasma NEFA and blood glycerol concentrations.

Somatostatin infusion alone resulted in a rise in blood ketone body concentrations, significant compared to saline from 60 min onwards. Similarly blood ketone body concentrations were elevated by growth hormone from $150 \mathrm{~min}$ onwards compared with the saline control. Combined growth hormone and somatostatin infusion exaggerated this ketone body rise (Fig. 2)

Blood concentrations of the gluconeogenic precursors lactate, pyruvate and alanine were unaltered by growth hormone with or without somatostatin infusion. Growth hormone had no effect on serum triglyceride concentrations at any time.

\section{Effects of Prolonged ( $24 \mathrm{~h})$ Growth Hormone Administration}

Table 2 shows the fasting concentrations of glucose, ketone bodies, NEFA, glycerol, growth hormone and insulin after prolonged growth hormone administration. Glucose was slightly but significantly increased whilst insulin concentrations had risen twofold. Blood ketone body and glycerol and plasma NEFA concentrations were unchanged after the overnight (12 h) fast.

The effect of prolonged growth hormone excess on the response of blood glucose and serum insulin concentrations to saline and somatostatin infusions is illustrated in Figure 3. During saline infusion after growth hormone blood glucose levels decreased slightly but remained $0.5 \mathrm{mmol} / 1$ higher than during the control infusion. Serum insulin concentrations were elevated two to threefold throughout. Somatostatin infusion produced a greater hyperglycaemic effect of growth hormone with blood glucose levels $1-1.5 \mathrm{mmol} / \mathrm{l}$ higher than during somatostatin infusion alone. Insulin levels were suppressed as with somatostatin alone.

Ketone body levels did not change during saline infusion but as in the acute experiments an effect of growth hormone to increase ketone body concentra- 


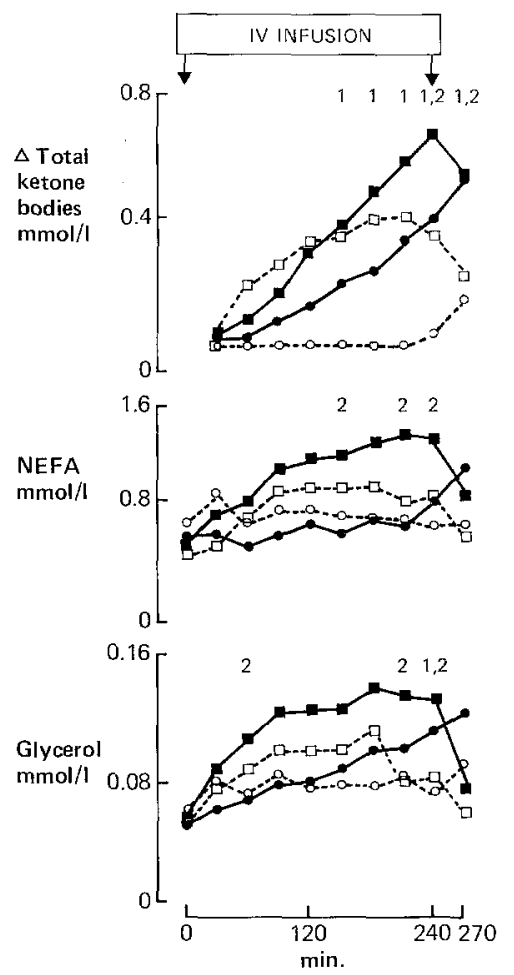

Fig. 2. Plasma non-esterified fatty acids (NEFA), blood glycerol and the change from basal in blood total ketone body concentrations during infusions of saline or growth hormone $(500 \mu \mathrm{g} / \mathrm{h})$ with and without somatostatin $(100 \mu \mathrm{g} / \mathrm{h})$. Conditions and symbols as for Figure 1. Total ketone bodies refers to the sum of blood 3-hydroxybutyrate and acetoacetate concentrations

Table 2. Effect of $24 \mathrm{~h}$ growth hormone administration on overnight $(12 \mathrm{~h})$ fasting glucose, ketone body, glycerol, non-esterified fatty acid and insulin concentrations

\begin{tabular}{llll}
\hline Hormone or metabolite & $\begin{array}{l}\text { Chronic } \\
\text { growth } \\
\text { hormone }\end{array}$ & Control & $\mathrm{p}$ \\
\hline $\begin{array}{l}\text { Blood glucose mmol/1 } \\
\text { Blood total ketone }\end{array}$ & $5.1 \pm 0.2$ & $4.6 \pm 0.3$ & $<0.05$ \\
bodies mmol/1 & $0.28 \pm 0.08$ & $0.20 \pm 0.05$ & $\mathrm{NS}$ \\
$\begin{array}{l}\text { Blood glycerol mmol/1 } \\
\begin{array}{l}\text { Plasma non-esterified } \\
\text { fatty acids mmol/l }\end{array}\end{array}$ & $0.07 \pm 0.02$ & $0.08 \pm 0.01$ & $\mathrm{NS}$ \\
Serum insulin mU/1 & $0.88 \pm 0.13$ & $0.66 \pm 0.10$ & $\mathrm{NS}$ \\
\hline
\end{tabular}

Growth hormone, $2 \mathrm{mg} \mathrm{IM}$, was administered $24 \mathrm{~h}$ and $12 \mathrm{~h}$ before sampling

Significance values obtained by Student's t-test for paired data

tions was unmasked by somatostatin infusion (Fig. 4). During saline infusion plasma NEFA concentrations were elevated by prolonged growth hormone alone. Simultaneous somatostatin infusion revealed a more marked lipolytic effect of growth hormone, producing an exaggerated rise in plasma NEFA and blood glycerol levels.

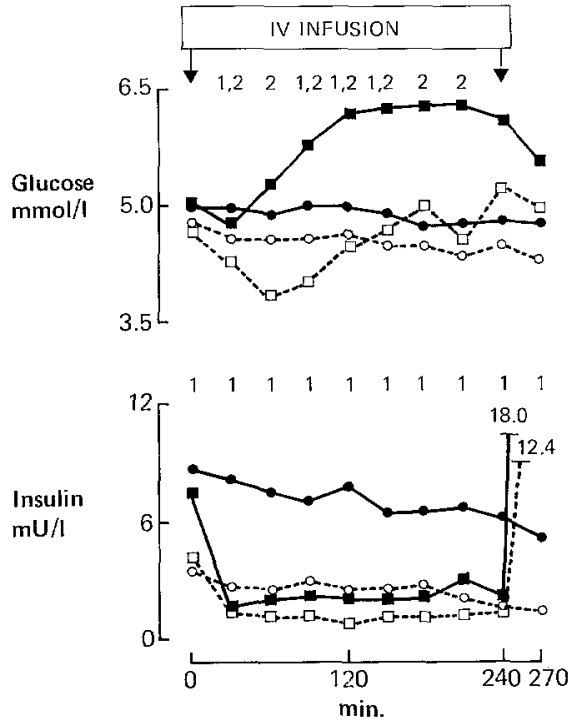

Fig. 3. Blood glucose and serum insulin concentrations during infusion of saline and somatostatin $(100 \mu \mathrm{g} / \mathrm{h})$ with and without administration of human growth hormone, $2 \mathrm{mg}$ intramuscularly $24 \mathrm{~h}$ and $12 \mathrm{~h}$ earlier. $1=$ values during saline infusion after growth hormone administration significantly different from those before ( $\mathrm{p}<0.05$ ). 2 = values during somatostatin infusion after growth hormone administration significantly different from those before $(\mathrm{p}<0.05)$. $\mathrm{O}---\mathrm{O}$ saline infusion, - - saline infusion after intramuscular growth hormone, $\square---\square$ somatostatin infusion, - - somatostatin infusion after intramuscular growth hormone

Concentrations of the gluconeogenic precursors, triglycerides, cortisol and glucagon were unaltered by previous growth hormone administration during both saline and somatostatin infusions (Table 1).

\section{Discussion}

The serum growth hormone concentrations obtained during acute intravenous infusions $(10-50 \mu \mathrm{g} / \mathrm{l})$ and after intramuscular injection should be comparable to those found in patients with diabetic ketoacidosis $[18,20]$, and severely ill traumatised subjects [21]. The growth hormone preparation was obtained from frozen pituitary glands [22] and is relatively free from contamination with other pituitary peptides [23].

A hyperglycaemic effect of growth hormone at pathophysiological concentrations has been known for many years. Hypophysectomy was shown in 1930 [24] to decrease the severity of diabetes in dogs and injection of anterior pituitary extracts produced hyperglycaemia in intact animals [5]. Similarly in non-diabetic hypophysectomised man, administration of pharmacological amounts of growth hormone decreased carbohydrate tolerance [8], while ketoacidosis was induced in hypophysectomised diabetics [7]. 


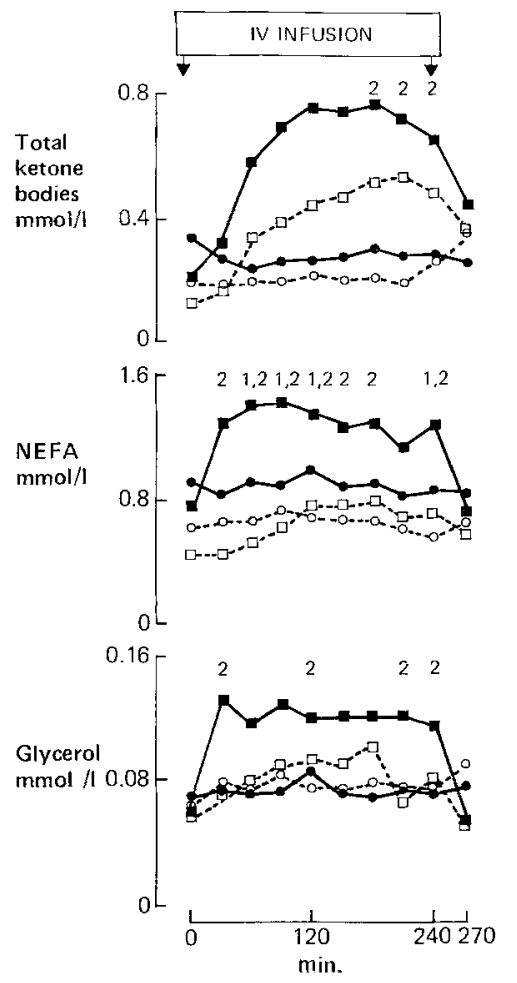

Fig. 4. Blood total ketone body, plasma non-estetified fatty acid (NEFA) and blood glycerol concentrations during infusion of saline and somatostatin $(100 \mu \mathrm{g} / \mathrm{h})$ with and without administration of human growth hormone, $2 \mathrm{mg}$ intramuscularly, $24 \mathrm{~h}$ and $12 \mathrm{~h}$ earlier. Conditions and symbols as for Figure 3. Total ketone bodies refers to the sum of blood 3-hydroxybutyrate and acetoacetate concentrations

In normal man the evidence for a hyperglycaemic effect of growth hormone is more tenuous. Intravenous administration of pharmacological doses of growth hormone decreases glucose tolerance within 1 to $2 \mathrm{~h}$ in normal subjects [25]. In our study growth hormone had no effect on blood glucose levels over the $4 \mathrm{~h}$ of acute infusion. The absence of a hyperglycaemic action of growth hormone in normal subjects may be explained by the simultaneous increase in insulin secretion (Fig. 1). This has previously been shown by other workers $[26,27]$ although a decrease in insulin secretion has also been observed [28].

$24 \mathrm{~h}$ growth hormone administration was associated with mild fasting hyperglycaemia. This is in keeping with the findings in acromegaly, in which the prevalence of glucose intolerance is ten times greater than in the normal population [29]. Nonetheless the hyperglycaemic action of more prolonged growth hormone elevation may have homeostatic importance as illustrated by the occasional occurrence of hypoglycaemia in children with isolated growth hormone deficiency [30]. In normal man, growth hormone is secreted in a pulsatile fashion with levels frequently approaching those attained in our study. Our data suggests that persistently elevated serum growth hormone concentrations, although having no immediate effect on blood glucose concentrations, may have a longer term hyperglycaemic action in normal subjects.

A more marked hyperglycaemic action of growth hormone was unmasked when insulin secretion was diminished by somatostatin infusion. In the acute studies, this was apparent after $2 \mathrm{~h}$ and contrasts with the findings of Gerich et al. [11] who found no hyperglycaemic action of growth hormone in severely insulin-deprived diabetic subjects, although serum levels achieved in their study were considerably lower $(6-8 \mu \mathrm{g} / \mathrm{l})$. Growth hormone stimulates glucagon secretion in the dog [31], but there is no evidence from our or other studies that this is a major action of growth hormone in man.

After $24 \mathrm{~h}$ growth hormone administration, its hyperglycaemic action was again exaggerated by somatostatin-induced insulin deficiency. It is apparent that the chronic moderately elevated growth hormone concentrations in poorly controlled, and probably insulin-deficient, diabetics could contribute to the hyperglycaemia observed.

In keeping with other studies [11], a hyperketonaemic action of growth hormone was apparent after both acute and prolonged exposure to high circulating concentrations. This may result from increased lipolysis and increased NEFA supply for ketogenesis or from a primary action of growth hormone on hepatic ketone body production or peripheral utilisation. In vitro and in vivo work has shown a lipolytic action of growth hormone at pharmacological doses [32, 33]; increased lipolysis was not apparent in our acute studies in normal subjects as reflected by plasma NEFA or blood glycerol concentrations, although it was after prolonged exposure. The absence of a lipolytic action in the acute studies may have been secondary to stimulated insulin secretion as lipolysis is exquisitely sensitive to small changes in peripheral insulin concentrations [34]. In addition a lag period of $1-2 \mathrm{~h}$ for the lipolytic action of growth hormone has been noted in vitro [35]. When insulin secretion was suppressed by somatostatin the lipolytic effect of growth hormone was seen at $150 \mathrm{~min}$ in the acute study and throughout the infusion period after prolonged chronic growth hormone administration demonstrating an important lipolytic action of growth hormone in insulin deficiency.

Increased ketosis in the absence of enhanced lipolysis in normal subjects suggests a direct effect of growth hormone on hepatic ketogenesis. Experiments with isolated perfused liver preparations have failed to demonstrate any such action [36], although there is suggestive evidence from other data in man [37]. The hepatic actions of growth hormone require further study. In insulin-deficiency and after pro- 
longed administration in normal subjects, the ketogenic actions of growth hormone are explicable at least in part by the actions on lipolysis, as suggested by others. In diabetic ketoacidosis and in poorly controlled insulin-dependent diabetics the elevated circulating growth hormone concentrations $[18,20]$ may contribute significantly to the metabolic abnormalities observed.

\section{References}

1. Johansen K, Hansen AP (1969) High 24 hour levels of serum growth hormone in juvenile diabetics. Br Med J: 356-357

2. Hansen AP, Johansen K (1970) Diurnal pattern of blood glucose, serum FFA, insulin, glucagon and growth hormone in normals and juvenile diabetics. Diabetologia 6: 27-33

3. Hansen AP (1971) Normalisation of growth hormone hyperresponse to exercise in juvenile diabetics after normalisation of blood sugar. J Clin Invest 50: 1806-1811

4. Merimee TJ, Fitzgerald CR, Gold LA, McCourt JP (1979) Characteristics of growth hormone secretion in clinically stable diabetes. Diabetes 28: 308-312

5. Young FG (1937) Permanent experimental diabetes produced by pituitary (anterior lobe) injections. Lancet II: 372-374

6. Houssay BA, Anderson E (1949) Diabetogenic action of purified anterior pituitary hormones. Endocrinology 45: $627-631$

7. Ikkos D, Luft R, Gemzell C, Almquist S (1962) Effect of human growth hormone on glucose tolerance and some intermediary metabolites in man. Acta Endocrinol (Kbh) 39: 547-566

8. Ikkos D, Luft R (1962) Effect of short-term administration of large doses of human growth hormone on carbohydrate metabolism in adult, non-diabetic, hypophysectomised women; studies with 14C-labelled glucose. Acta Endocrinol (Kbh) 39: 567-583

9. Weil R (1965) Pituitary growth hormone and intermediary metabolism. Acta Endocrinol [Suppl 98] (Kbh) 49: 5-92

10. Luft R, Ikkos D (1958) Effect of growth hormone in hypophysectomised diabetic subjects. Lancet I: 721-722

11. Gerich JE, Lorenzi M, Bier DM, Tsalikian E, Schneider V, Karam JH, Forsham PH (1976) Effects of physiological levels of glucagon and growth hormone on human carbohydrate and lipid metabolism. J Clin Invest 57: 875-884

12. Lloyd B, Burrin J, Smythe P, Alberti KGMM (1978) Simple automated enzymatic fluorimetric assays for blood glucose, lactate, pyruvate, alanine, glycerol and 3-hydroxybutyrate. Clin Chem 24: 1724-1729

13. Price CP, Lloyd B, Alberti KGMM (1977) A kinetic spectrophotometric assay for rapid determination of acetoacetate in blood. Clin Chem 23: 1893-1897

14. Ho RT, Meng HC (1969) A simple and ultrasensitive method for determination of FFA by radiochemical assay. Anal Biochem 31: 425-436

15. Postle A, Goodland FC (1978) A comparison of three automated methods of serum triglyceride analysis. Ann Clin Biochem 15: 18-24

16. Boden G, Soeldner JS (1967) A sensitive double antibody radioimmuoassay for human growth hormone (HGH). Levels of $\mathrm{HGH}$ following rapid tolbutamide infusion. Diabetologia 3 : 413-421

17. Soeldner J, Slone D (1965) Critical variables in the radioimmunoassay of serum insulin using the double antibody technique. Diabetes 14: 771-779

18. Alberti KGMM, Christensen NJ, Iversen J, Ørskov H (1975) The role of glucagon and other hormones in the development of diabetic ketoacidosis. Lancet I: 1307-1311
19. Baum CK, Tudor R, Landon J (1974) A simple competitive protein binding assay for plasma cortisol. Clin Chim Acta 55: 147-154

20. Chernick SS, Clark CM Jr, Gardiner RJ, Scow RO (1972) Role of lipolytic and glucocorticoid hormones in the development of diabetic ketosis. Diabetes 21: 946-954

21. Batstone GF, Alberti KGMM, Hinks L (1976) Metabolic studies in subjects following thermal injury: intermediate metabolites, hormones and tissue oxygenation. Burns 2: 207-225

22. Roos, R, Fevold HR, Gemzell CA (1963) Preparations of human growth hormone by gel filtration. Biochim Biophys Acta 74: 525-531

23. Holmstrom B, Fholenhag K (1975) Characterisation of human growth hormone preparations used for the treatment of pituitary dwarfism: a comparison of concurrently used batches. J Clin Endocrinol Metab 40: 856-862

24. Houssay BA, Biasotti A (1930) La diabetes pancreatica de los perros - hipofiseoprivos. Rev Soc Argent Biol 6: 251-258

25. Hierler KL, Rabinowitz D (1963) Roles of insulin and growth hormone based on studies of forearm metabolism in man. Medicine (Baltimore) 42: 385-402

26. Luft R (1969) The effects of moderate and high doses of human growth hormone on the insulin response to glucose infusion in prediabetic subjects. Horm Metab Res 1: 111-118

27. Merimee TJ (1967) Influence of growth hormone on insulin secretion. Studies of growth hormone deficient subjects. Diabetes 16: 478-482

28. Adamson U, Wahren J, Cerasi E (1977) Influence of growth hormone on splanchnic glucose production in man. Acta Endocrinol (Kbh) 86: 803-812

29. Lazarus S, Volk B (1962) In: The pancreas in human and experimental diabetes. Grune \& Stratton, New York

30. Merimee TJ, Felig P, Marliss E, Fineberg SE, Cahill GF Jr (1971) Glucose and lipid homeostasis in the absence of human hormone. J Clin Invest 50: 574-582

31. Sirek A, Vranic M, Sirek Ou, Vigas M, Policova Z (1979) Effect of growth hormone on acute glucagon and insulin release. Am J Physiol 6: 107-112

32. Caldwell AB, Fain JN (1970) Inhibition by cycloheximide and dactinomycin of the activation of lipolysis due to growth hormone in white fat cells. Horm Metab Res 2: 3-5

33. Goodman HM, Schwartz J (1974) Growth hormone and lipid metabolism. In: Handbook of physiology, Section 7: Endocrinology 4. American Physiological Society, Washington DC, p 211-231

34. Nestel PH, White HM (1967) Relationship between FFA flux and TFGA influx in plasma before and during the infusions of insulin. Metabolism 16: 1123-1132

35. Fain JN (1968) Effect of dibutyryl-3',5'-AMP, theophylline and norepinephrine on the lipolytic action of growth hormone and glucocorticoids in white fat cells. Endocrinology 82: 825-830

36. Penhos JC, Wu CH, Lemberg A, Daunas J, Brodoff B, Levine $\mathrm{R}$ (1966) The effect of growth hormone on the metabolism of lipids and on urea formation by the perfused rat liver. Metabolism 15: 1109-1119

37. Schade DS, Eaton RP, Peake GT (1978) The regulation of plasma ketone body concentration by counter-regulatory hormones in man. Diabetes 27: 916-924

Received: May 23, 1980,

and in revised form: August 14, 1980

Dr. D. G. Johnston

Department of Medicine

Royal Victoria Infirmary

Newcastle upon Tyne NEI 4LP

England 